\title{
Incubation periods and sex ratios of green turtles: highly female biased hatchling production in the eastern Mediterranean
}

\author{
A. C. Broderick ${ }^{1, *}$, B. J. Godley ${ }^{1}$, S. Reece $^{2}$, J. R. Downie ${ }^{2}$ \\ ${ }^{1}$ Marine Turtle Research Group, School of Biological Sciences, University of Wales, Swansea SA2 8PP, Wales, UK \\ ${ }^{2}$ Division of Environmental and Evolutionary Biology, Institute of Biomedical and Life Sciences, University of Glasgow, \\ Glasgow G12 8QQ, Scotland, UK
}

\begin{abstract}
Marine turtles are globally endangered and subject to numerous conservation and management initiatives, yet many aspects of their life histories remain undescribed. All populations subject to investigation have been shown to have temperature dependent sex determination, and data in a number of cases have suggested that the sex ratio of hatchling production may be highly female biased. To date, the green turtle Chelonia mydas has been little studied in this respect. We recorded the temperature in 18 green turtle clutches laid at Alagadi Beach, Northern Cyprus using automated intra-nest recording devices. The temperatures experienced within these clutches ranged from 26.7 to $34.1^{\circ} \mathrm{C}$ with mean temperature ranging from 29.8 to $32.5^{\circ} \mathrm{C}$. No regular diel thermal cycle was observed. Incubation periods at this site decreased as the season progressed and ranged from 43 to $60 \mathrm{~d}(\mathrm{n}=231 ; 1993$ to 1998). In comparison to other published studies regarding temperature dependent sex determination in this species, these data are strongly suggestive of a highly female biased hatchling sex ratio. This hypothesis was partly confirmed utilising histological sexing of hatchlings found dead in nests ( $>99 \%$ female in 1998, $n=231$ ). From these data we estimate that the pivotal incubation period for this population is $\geq 56 \mathrm{~d}$ and the pivotal temperature as below $29.2^{\circ} \mathrm{C}$. Using a conservative assumption that $100 \%$ males are produced by nests with incubation periods $\geq 56 \mathrm{~d}$ and $100 \%$ females are produced by nests with shorter incubations, for the years 1993 to 1998, we estimate that at least 86 to $96 \%$ of hatchlings produced at this site were female.
\end{abstract}

KEY WORDS: Marine turtle · Chelonia mydas · Temperature · Hatching · Environmental sex determination

Resale or republication not permitted without written consent of the publisher

\section{INTRODUCTION}

In many reptilian species, including sea turtles, the sex of the offspring is dependent on incubation temperatures and is not genetically determined at the time of egg deposition. This temperature dependent sex determination (TSD) is exhibited in different patterns among different reptile groups (Janzen \& Paukstis 1991). In the marine turtle species studied to date, higher temperatures have been shown to produce a greater proportion of females, with cooler temperatures producing more males (see Mrosovsky 1994 for

*E-mail: mtn@swan.ac.uk review). The temperature experienced during the thermosensitive period, thought to occur during the middle third of incubation, is critical for sexual development. The temperature at which a 1:1 sex ratio is produced is termed the pivotal temperature (Yntema \& Mrosovsky 1980, Miller \& Limpus 1981, Spotila et al. 1987, Mrosovsky \& Pieau 1991). Although the possibility for some degree of interpopulation variation in patterns of TSD in at least some sea turtle species exists (Chevalier et al. 1999), pivotal temperatures have been shown to be conservative (Mrosovsky 1994).

A number of population specific factors have been described as affecting nest temperatures and hence sex ratios of marine turtles. These include: latitudinal variation, seasonal temperature changes, shading by 
vegetation, sand colour, episodic events such as rain and depth of the eggs (Morreale et al. 1982, Mrosovsky et al. 1984, Mrosovsky 1988, Hays et al. 1999).

Studies determining the pivotal temperature and sex ratio of hatchling production in marine turtle populations have employed several different techniques including: laboratory incubation of eggs under controlled thermal regimes (Mrosovsky \& Yntema 1980, Miller \& Limpus 1981, Billett et al. 1992, Georges et al. 1994); inferences from long term control site temperature monitoring at nest depth (Limpus et al. 1983, Mrosovsky et al. 1984, Godfrey et al. 1996); intra-nest temperature logging (Spotila et al. 1987, Kaska et al. 1998); and inferences from incubation periods (Marcovaldi et al. 1997). This latter technique utilises the fact that the duration of incubation period is related to intra-nest temperature, so that a pivotal incubation period, i.e. that which produces a 1:1 sex ratio, can be calculated. This technique has recently been validated (Mrosovsky et al. 1999).

The major challenge to this area of study is the difficulty in accurately determining the sex of hatchlings. The most commonly used method is that of sexing hatchlings from gonadal morphology upon histological examination (Yntema \& Mrosovsky 1980, Miller \& Limpus 1981, Dutton et al. 1984, Billett et al. 1992). This usually necessitates the sacrifice of study animals and, given the endangered and protected status of marine turtles, has led to many studies based on small sample sizes. Although an alternative exists in the use of hormone assay (Wibbels et al. 1991), this is a relatively costly and logistically challenging technique. An additional opportunity arises to sample hatchlings which die in the sand column during emergence (Wibbels et al. 1999). Although it must be considered that these samples may be the result of a sex specific neonatal mortality factor, data derived from such studies can be from a large selection of nests and, in combination with other techniques, can give an insight into the likely sex ratio of hatchling production of the population.

Of the marine turtles, the most scrutinised has been the loggerhead turtle Caretta caretta, in which some populations have been demonstrated as showing extremely female biased hatchling production (Mrosovsky \& Provancha 1989, 1992, Marcovaldi et al. 1997). Data regarding TSD in the green turtle Chelonia mydas are relatively scant. In a laboratory based study, Miller \& Limpus (1981) suggested a pivotal temperature exists between 26 and $29^{\circ} \mathrm{C}$ for green turtles nesting on the Great Barrier Reef. Whilst Limpus et al. (1983) demonstrated spatial variation in the hatchling sex ratio of this population, no quantitative estimates of overall sex ratio were provided. Evidence from more recent studies on green turtles suggests that the pivotal temperature for this species is more likely to fall at the higher end of the range suggested by Miller \& Limpus (1981).

Work over a number of seasons on the green turtles nesting in Suriname (Mrosovsky et al. 1984, Godfrey et al. 1996) has used progressive statistical refinements resulting in 2 separate estimates of a pivotal temperature of 29.1 or $29.4^{\circ} \mathrm{C}$ (Godfrey 1997). Godfrey et al. (1996) estimated that, dependent on variation in weather patterns, the ratio of female hatchlings produced in Suriname ranged between 20 and $90 \%$ in different years. In Tortuguero, Costa Rica, by measurement of intra-nest temperatures, an estimated pivotal range of 28 to $30^{\circ} \mathrm{C}$ was generated, and hatchling production was estimated as $67 \%$ female (Standora \& Spotila 1985, Spotila et al. 1987). Higher male ratios $(94 \%)$ were however recorded in nests shaded by vegetation. In a preliminary study of 5 green turtle nests in Northern Cyprus using intra-nest data loggers, placed at the top, middle and bottom of the clutch, Kaska et al. (1998) estimated the pivotal temperature in this population to be just below $29^{\circ} \mathrm{C}$. No attempt was made in this study to generate overall sex ratios of hatchling production in the population. Although temperature differences were found within clutches, these were small (range $\leq 0.8^{\circ} \mathrm{C}$; with cooler temperatures recorded at the bottom of clutches).

In the present study we examine the role played by temperature as an influence on the incubation periods and sex ratio of green turtle hatchlings produced at Alagadi Beach, Northern Cyprus in the eastern Mediterranean: (1) We investigate temperature regimes experienced in 18 green turtle nests utilising intra-nest temperature recording devices. (2) We describe incubation periods over 6 seasons (1993 to 1998) and investigate the role of temperature as an influence on the duration of incubation periods. (3) We describe the sex ratio in a large sample of non-invasively collected hatchlings from nests hatched in 1998. (4) From these data and known information regarding the role of temperature in the determination of sex in green turtle populations elsewhere, we draw wider inferences as to the likely sex ratio of hatchlings produced from this rookery and others in the region.

\section{METHODS}

Study site. This study was largely conducted on Ala-

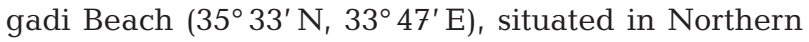
Cyprus in the eastern Mediterranean. There is a high level of human traffic on this $2 \mathrm{~km}$ beach; however, beach umbrellas and shades are only used at the water's edge, in the region where no green turtle clutches are laid. Additional limited data were collected from other more remote green turtle nesting 
beaches on the island, which were not subject to any recreational use. No nests experienced any shading on these beaches.

Data collection. At Alagadi, both laying and hatching were monitored between May and October between 1993 and 1998 through nightly patrols and daily dawn beach surveys according to a previously described protocol (Broderick \& Godley 1996). Other beaches were surveyed every $2 \mathrm{~d}$ throughout the season of 1998. Nest temperatures were recorded using 'Tinytalk' data loggers (Orion Components Ltd, Chichester, UK, accuracy $\pm 0.4^{\circ} \mathrm{C}$ ), which had been calibrated with a mercury thermometer of known accuracy (NAMAS certified to read within $0.1^{\circ} \mathrm{C}$ of the absolute temperature; Hays et al. 1999). The logger was placed into the middle of the clutch of eggs during oviposition, and the female was allowed to cover the nest. Temperature was recorded at sampling intervals of 48 min in a total of 18 clutches between 1995 and 1998. Data recorded from laying until midnight on the first night of hatchling emergence were included in our analysis. The positions of all nests were recorded in relation to marker posts placed at $50 \mathrm{~m}$ intervals at the back of the beach. In addition, a numbered plastic marker was placed in the sand above the egg chamber as the female began to cover her eggs. Upon hatching, nest contents, including dataloggers where present, were excavated and the nest tag located. Nest tags allowed $100 \%$ correlation with the laying event, a process difficult to ensure simply by using nest positions when high density nesting occurs. Incubation periods were calculated as the number of days between the night on which the clutch was laid until the night on which the first group of hatchlings emerged. The date prior to midnight of the night in question was taken in all cases.

Collection of hatchlings for sexing. Dead hatchlings were collected at post-hatching excavation (after a period of $48 \mathrm{~h}$ with no hatchling emergence) from nests of known incubation periods. The sex of hatchlings was determined using standard histological techniques (Yntema \& Mrosovsky 1980, Miller \& Limpus 1981, Dutton et al. 1984, Billett et al. 1992).

\section{RESULTS}

\section{Temperatures}

Lay dates, incubation periods and summary incubation temperature data recorded are presented in Table 1. Temperatures ranged between 26.7 and $34.1^{\circ} \mathrm{C}$ with mean incubation temperatures ranging from 29.8 to $32.5^{\circ} \mathrm{C}$. During the middle third of incubation, temperatures ranged from 28.8 to $34.1^{\circ} \mathrm{C}$ with means ranging from 29.7 to $32.8^{\circ} \mathrm{C}$. Fig. 1 illustrates the temperature profiles in 2 clutches (Clutches 9 and 18, the first and last laid in 1998) throughout the incubation period. No diel temperature cycle was recorded in any of the 18 study nests. Mean daily range for the 18 nests varied between 0.07 and $0.18^{\circ} \mathrm{C}$ (Table 1).

For the 10 clutches that we monitored in 1998, we averaged all the readings for each 48 min sampling interval to produce a composite seasonal profile of the

Table 1. Laying date, incubation periods and temperature data $\left({ }^{\circ} \mathrm{C}\right)$ for the 18 clutches in which temperature was monitored. IP: incubation period

\begin{tabular}{|c|c|c|c|c|c|c|c|c|c|c|c|c|c|c|}
\hline \multirow[t]{2}{*}{ Nest } & \multirow{2}{*}{$\begin{array}{l}\text { Lay } \\
\text { date }\end{array}$} & \multirow[t]{2}{*}{$\mathrm{IP}(\mathrm{d})$} & \multicolumn{4}{|c|}{$\longrightarrow$ Total IP $\longrightarrow$} & \multicolumn{4}{|c|}{$\longrightarrow$ Middle third IP -} & \multicolumn{4}{|c|}{ - Daily range } \\
\hline & & & Mean & $\pm \mathrm{SD}$ & Min & Max & Mean & $\pm \mathrm{SD}$ & Min & Max & Mean & $\pm \mathrm{SD}$ & Min & $\operatorname{Max}$ \\
\hline 1 & 22 Jun 95 & 53 & 30.6 & 1.57 & 28.1 & 33.0 & 30.2 & 0.63 & 29.4 & 31.6 & 0.14 & 0.22 & 0 & 0.5 \\
\hline 2 & 25 Jun 95 & 50 & 30.8 & 1.05 & 28.9 & 32.1 & 30.6 & 0.51 & 29.8 & 31.6 & 0.07 & 0.22 & 0 & 0.5 \\
\hline 3 & 28 Jun 96 & 51 & 30.7 & 1.12 & 26.8 & 32.5 & 30.8 & 0.40 & 29.8 & 31.6 & 0.09 & 0.24 & 0 & 0.5 \\
\hline 4 & 16 Jun 97 & 50 & 31.0 & 1.80 & 26.7 & 33.3 & 31.2 & 0.54 & 30.3 & 32.1 & 0.18 & 0.20 & 0 & 0.7 \\
\hline 5 & 26 Jun 97 & 51 & 30.0 & 1.20 & 28.1 & 31.8 & 29.7 & 0.59 & 28.8 & 31.1 & 0.14 & 0.19 & 0 & 0.5 \\
\hline 6 & 27 Jun 97 & 50 & 31.1 & 0.94 & 28.8 & 32.5 & 31.2 & 0.54 & 30.3 & 32.1 & 0.13 & 0.18 & 0 & 0.5 \\
\hline 7 & 29 Jun 97 & 48 & 31.4 & 0.98 & 29.2 & 32.9 & 31.3 & 0.55 & 30.6 & 32.1 & 0.12 & 0.19 & 0 & 0.5 \\
\hline 8 & $10 \mathrm{Jul} 97$ & 50 & 31.2 & 1.17 & 29.4 & 33.0 & 31.0 & 0.58 & 30.3 & 32.5 & 0.16 & 0.22 & 0 & 0.5 \\
\hline 9 & 09 Jun 98 & 53 & 30.3 & 1.58 & 27.0 & 32.6 & 30.6 & 0.57 & 29.6 & 31.1 & 0.13 & 0.18 & 0 & 0.4 \\
\hline 10 & 15 Jun 98 & 52 & 30.2 & 1.70 & 27.4 & 33.0 & 30.1 & 0.46 & 29.2 & 31.1 & 0.16 & 0.19 & 0 & 0.4 \\
\hline 11 & 21 Jun 98 & 51 & 30.6 & 1.26 & 28.1 & 32.5 & 30.4 & 0.44 & 29.8 & 31.6 & 0.12 & 0.20 & 0 & 0.5 \\
\hline 12 & 02 Jul 98 & 50 & 31.4 & 1.32 & 29.6 & 33.3 & 31.1 & 0.62 & 30.3 & 32.2 & 0.13 & 0.18 & 0 & 0.4 \\
\hline 13 & 09 Jul 98 & 54 & 29.9 & 1.16 & 27.4 & 31.8 & 30.0 & 0.53 & 29.2 & 30.7 & 0.11 & 0.21 & 0 & 1.1 \\
\hline 14 & 09 Jul 98 & 48 & 31.8 & 1.12 & 29.9 & 34.1 & 32.4 & 0.90 & 31.4 & 34.1 & 0.14 & 0.19 & 0 & 0.4 \\
\hline 15 & $17 \mathrm{Jul} 98$ & 48 & 31.5 & 0.66 & 28.8 & 32.1 & 31.8 & 0.36 & 31.1 & 32.1 & 0.11 & 0.18 & 0 & 0.5 \\
\hline 16 & $18 \mathrm{Jul} 98$ & 54 & 29.8 & 0.66 & 28.4 & 30.7 & 29.9 & 0.24 & 29.6 & 30.3 & 0.07 & 0.15 & 0 & 0.4 \\
\hline 17 & $21 \mathrm{Jul} 98$ & 46 & 32.5 & 0.62 & 30.3 & 33.3 & 32.8 & 0.22 & 32.1 & 32.9 & 0.13 & 0.19 & 0 & 0.4 \\
\hline 18 & 01 Aug 98 & 43 & 32.0 & 0.59 & 29.2 & 32.9 & 31.7 & 0.34 & 31.4 & 32.5 & 0.15 & 0.19 & 0 & 0.5 \\
\hline
\end{tabular}



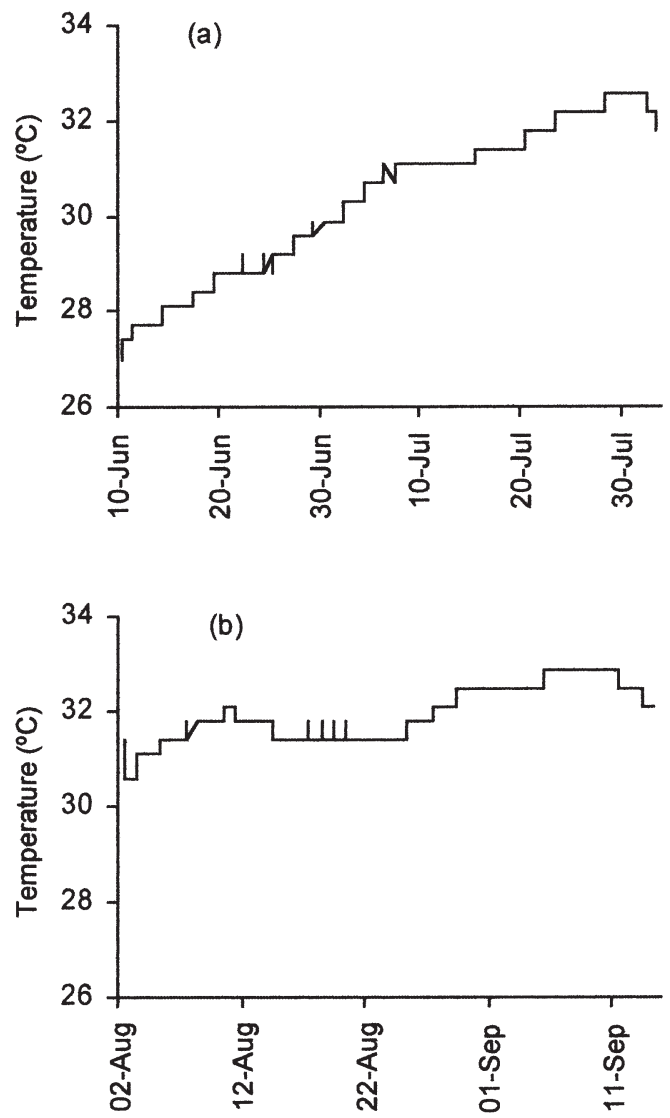

Fig. 1. Temperature profiles of (a) Clutch 9, laid on 9 June 1998 and hatched on 1 August 1998 after an incubation period of 53 d. (b) Clutch 18, laid on 1 August 1998 and hatched on 13 September after an incubation period of $43 \mathrm{~d}$. Temperature shown is that recorded every $48 \mathrm{~min}$ throughout incubation

mean incubation temperatures experienced in this year (Fig. 2a). Apart from a period of $1 \mathrm{wk}$ at the start and end of the season $\geq 2$ nests were monitored concurrently. In general, the among nest variance was not high with mean range of temperature for all $48 \mathrm{~min}$ sampling intervals being $2.5^{\circ} \mathrm{C}$ (range 0.4 to $4.2, \mathrm{SD}=$ $1.05, \mathrm{n}=2617$ ). There was a pronounced seasonal pattern, with temperatures building through June and July, staying relatively high and constant in August, and gradually decreasing at the start of September. The increase in the variance of temperature on 5 September was due to the hatching of a nest, leaving only 2 study nests. The marked increase in temperature on 11 September was a result of the hatching of the penultimate nest.

To account for the temporal distribution of nesting, for each week of the 1998 season the proportion (\%) of nests in the middle third of incubation was calculated (Fig. 2b). During this period few nests experienced thermal conditions likely to result in the production of a male biased sex ratio (>90\% nests reach the middle third of incubation when mean temperatures are already well in excess of $29^{\circ} \mathrm{C}$, the thermal region where most pivotal temperatures have been demonstrated; Mrosovsky 1994). This suggests that the sex ratio of hatchlings produced at this site will be heavily female biased.

\section{Incubation periods}

The incubation periods recorded at Alagadi Beach over the $6 \mathrm{yr}$ of this study ranged from 43 to $60 \mathrm{~d}$ (Table 2). The mean incubation period recorded for each of the study years ranged from 48.0 to $51.4 \mathrm{~d}$. Mean incubation period recorded in 1998 was significantly shorter than that of 1994 (ANOVA: $F=3.25$, $\mathrm{p}=0.008, \mathrm{df}=5, \mathrm{n}=231$; followed by a Tukey test for unequal samples; Zar 1999).
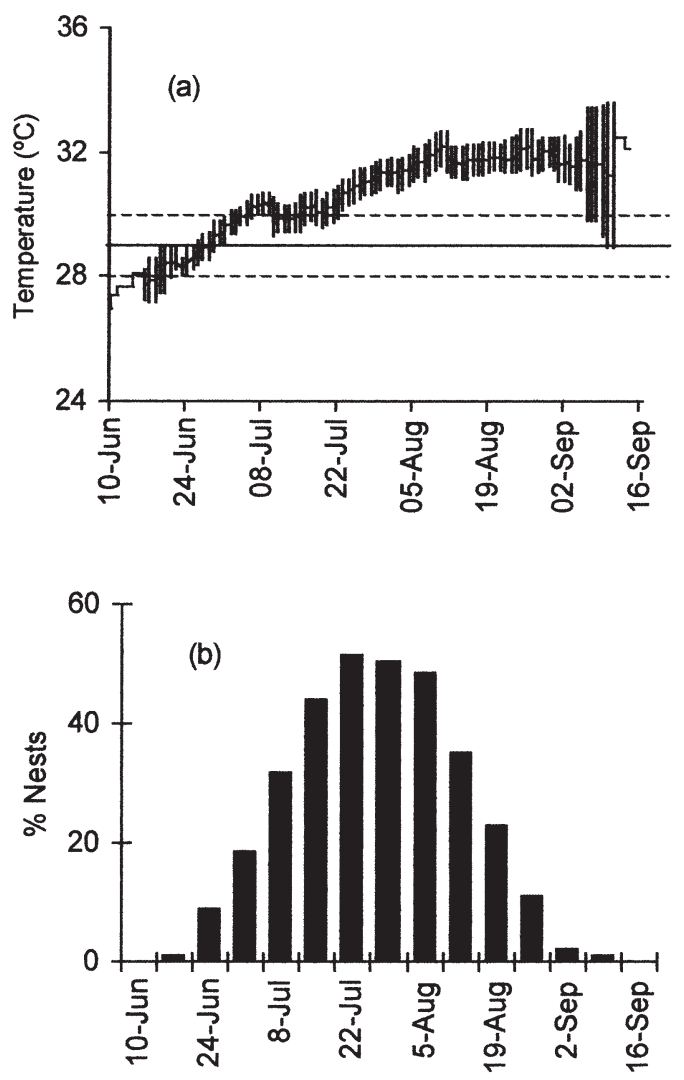

Fig. 2. (a) Composite seasonal profile of mean temperatures (with SE bars every 25th value) recorded within 10 clutches in 1998. Solid line indicates $29^{\circ} \mathrm{C}$; the approximate pivotal temperature of green turtles previously reported (Godfrey 1997, Kaska et al. 1998). Broken lines signify 28 and $30^{\circ} \mathrm{C}_{\text {; the range }}$ in which pivotal temperatures are likely to fall (Spotila et al. 1987). (b) Weekly distribution $(\% ; n=91)$ of clutches in their middle third of incubation, Alagadi 1998. Note: All clutches are represented in 2 or 3 weekly bins 
Table 2. Mean incubation periods recorded at Alagadi Beach in each of the seasons 1993 to 1998. Parentheses give percentage of overall clutches laid that are included. IP: incubation period

\begin{tabular}{|c|c|c|c|c|c|}
\hline Year & Mean IP & $\pm \mathrm{SD}$ & Min & Max & $\mathrm{N}(\%)$ \\
\hline 1993 & 50.6 & 2.72 & 45 & 58 & $24(48.0)$ \\
\hline 1994 & 51.4 & 3.57 & 45 & 59 & 45 (66.2) \\
\hline 1995 & 50.8 & 3.63 & 44 & 60 & $51(79.7)$ \\
\hline 1996 & 48.0 & 5.07 & 44 & 58 & $7(87.5)$ \\
\hline 1997 & 50.2 & 2.89 & 46 & 57 & $13(100.0)$ \\
\hline 1998 & 49.3 & 3.48 & 43 & 58 & $91(82.0)$ \\
\hline Total & 50.2 & 3.57 & 43 & 60 & $231(73.6)$ \\
\hline
\end{tabular}

\section{Seasonal variation in incubation periods}

Fig. 3 illustrates the relationship recorded in 1998 between the date on which a nest was laid and incubation period. Regression analysis, conducted using day of the season (with Day 1 being that on which the first green turtle clutch was laid), showed this relationship to be statistically significant $(F=54.57, \mathrm{p}<0.001$, df $=$ $1, \mathrm{n}=91)$.

\section{Relationship between incubation period and temperature}

The regression line describing the relationship between mean incubation temperature and incubation period was calculated for the 18 nests containing temperature loggers $(F=58.25, \mathrm{p}<0.001$, df $=1$; Fig. $4 \mathrm{a})$. Residuals were found to be normally distributed (Anderson-Darling $\mathrm{p}>0.05)$. Furthermore, if incubation period is to allow reliable prediction of sex ratio, it

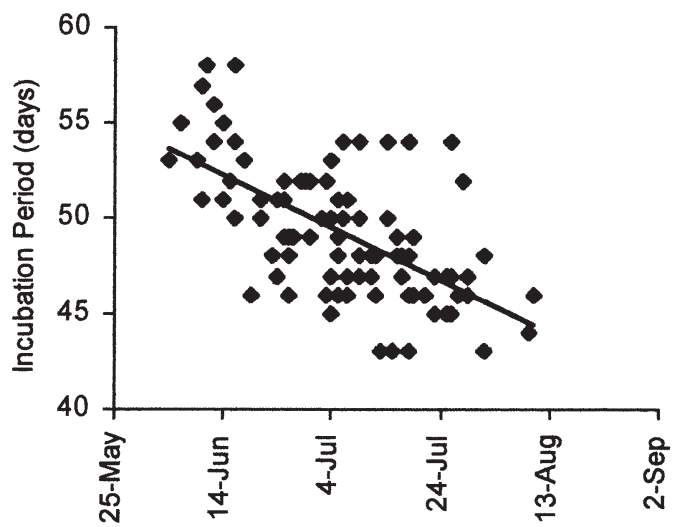

Fig. 3. Relationship between date on which a nest was laid and incubation period (IP) for 91 clutches laid in 1998, Alagadi Beach. (Eq. 1: IP $=53.8-0.138$ date, $r^{2}=0.38$ ). For date, Day 1 = first day a green turtle clutch was deposited (4 June 1998) must be strongly correlated with the mean temperature during the middle third of incubation. This was also found to be the case $(F=29.19, \mathrm{p}<0.001$, df $=1$; Fig. 4b).

\section{Actual sex ratios}

In 1998, 231 freshly dead hatchlings were collected from 44 nests of known incubation period at Alagadi and 13 hatchlings from 4 additional nests from the west coast of the island. The sex ratios of all nests, in comparison to incubation periods, are shown in Table 3. Males were only detected in nests with incubation periods of $\geq 56 \mathrm{~d}$.

\section{Estimating pivotal incubation period and pivotal temperature}

Whilst it is not possible to derive an absolute pivotal incubation period using these data (as per Marcovaldi et al. 1997, Mrosovsky et al. 1999), as no males were
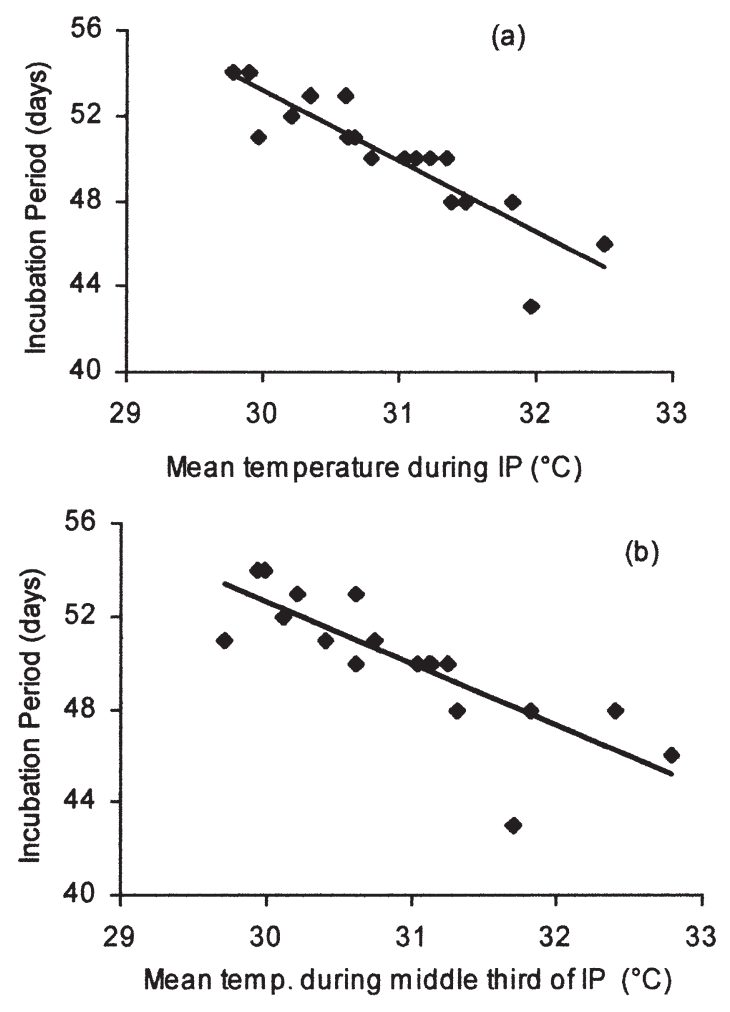

Fig. 4. (a) Relationship between incubation period and mean temperature throughout incubation period (IP). (Eq. 2: IP = 152 - 3.29 mean temperature throughout incubation, $\mathrm{r}^{2}=$ 0.79). (b) Relationship between IP and mean temperature during the middle third of incubation (Eq. 3: IP $=132-2.65$ mean temperature during the middle third of incubation, $\mathrm{r}^{2}=0.65$ ) 
Table 3. Results of histological sampling and sexing from nests of known incubation period (IP). Values in parentheses are number of hatchlings sampled from individual nests

\begin{tabular}{|lccc|}
\hline IP (d) & Nests (n) & Hatchlings (n) & $\%$ female \\
\hline 43 & 2 & $7(5,2)$ & 100 \\
45 & 1 & 1 & 100 \\
46 & 8 & $54(7,10,10,6,8,3,5,5)$ & 100 \\
47 & 6 & $32(6,4,1,7,6,8)$ & 100 \\
48 & 7 & $36(8,6,6,5,2,4,5)$ & 100 \\
49 & 2 & $14(8,6)$ & 100 \\
50 & 2 & $9(6,3)$ & 100 \\
51 & 3 & $16(4,7,5)$ & 100 \\
52 & 4 & $18(7,8,2,1)$ & 100 \\
53 & 1 & 5 & 100 \\
54 & 4 & $12(4,4,1,3)$ & 100 \\
55 & 1 & 9 & 100 \\
56 & 4 & $13(1,5,5,2)$ & $100^{\mathrm{a}}, 100,60,50^{\mathrm{a}}$ \\
57 & 1 & 8 & 100 \\
58 & 2 & $10(6,4)$ & $100^{\mathrm{a}}, 75^{\mathrm{a}}$ \\
a Denotes samples from a nesting beach on the west coast \\
of Cyprus & & \\
\hline \multicolumn{5}{|c}{} \\
\hline
\end{tabular}

found in samples from nests with incubation periods less than $56 \mathrm{~d}$, it is reasonable to assume that in this population the pivotal incubation duration is $\geq 56 \mathrm{~d}$. However, this must be treated as a minimum value. Substituting this value in Eq. (2) (incubation period and mean temperature) we can derive a pivotal temperature of $29.2^{\circ} \mathrm{C}$. However, this would be a maximum value. If we substitute $56 \mathrm{~d}$ incubation into Eq. (3) (incubation period and temperature during the middle third of incubation), a pivotal temperature of $28.7^{\circ} \mathrm{C}$ results. This too should be considered a maximum value.

\section{Estimation of sex ratio}

From these calculations it is possible to generate plausible estimates of sex ratio of hatchling production using incubation periods (at Alagadi in 1998: Fig. 5a; Alagadi between 1993 and 1998: Fig. 5b; and the rest of Northern Cyprus in 1998: Fig. 5c). If we assume that all nests with incubation periods of less than $56 \mathrm{~d}$ produce female biased offspring (considered as 100\% females) and all nests of $\geq 56 \mathrm{~d}$ incubation period produced male biased offspring (considered 100\% males), any estimate generated will give a conservative minimum proportion of females produced.

Based on these assumptions, it was estimated that $>96 \%$ of hatchlings produced in the 91 nests laid at Alagadi in 1998 were female (Fig. 5a). Data from the years 1993 to 1998 produced estimates ranging from 86 to $96 \%$ female, with a combined data set of 231 nests likely to have produced a sex ratio > $91 \%$ female (Fig. 5b). When nests from all other sites in Northern Cyprus (1998), excluding Alagadi were combined, they were estimated to have produced a sex ratio of $>71 \%$ female (Fig. 5c; 120 nests). Overall for 1998 in Northern Cyprus this gives an estimated $>82 \%$ females produced.
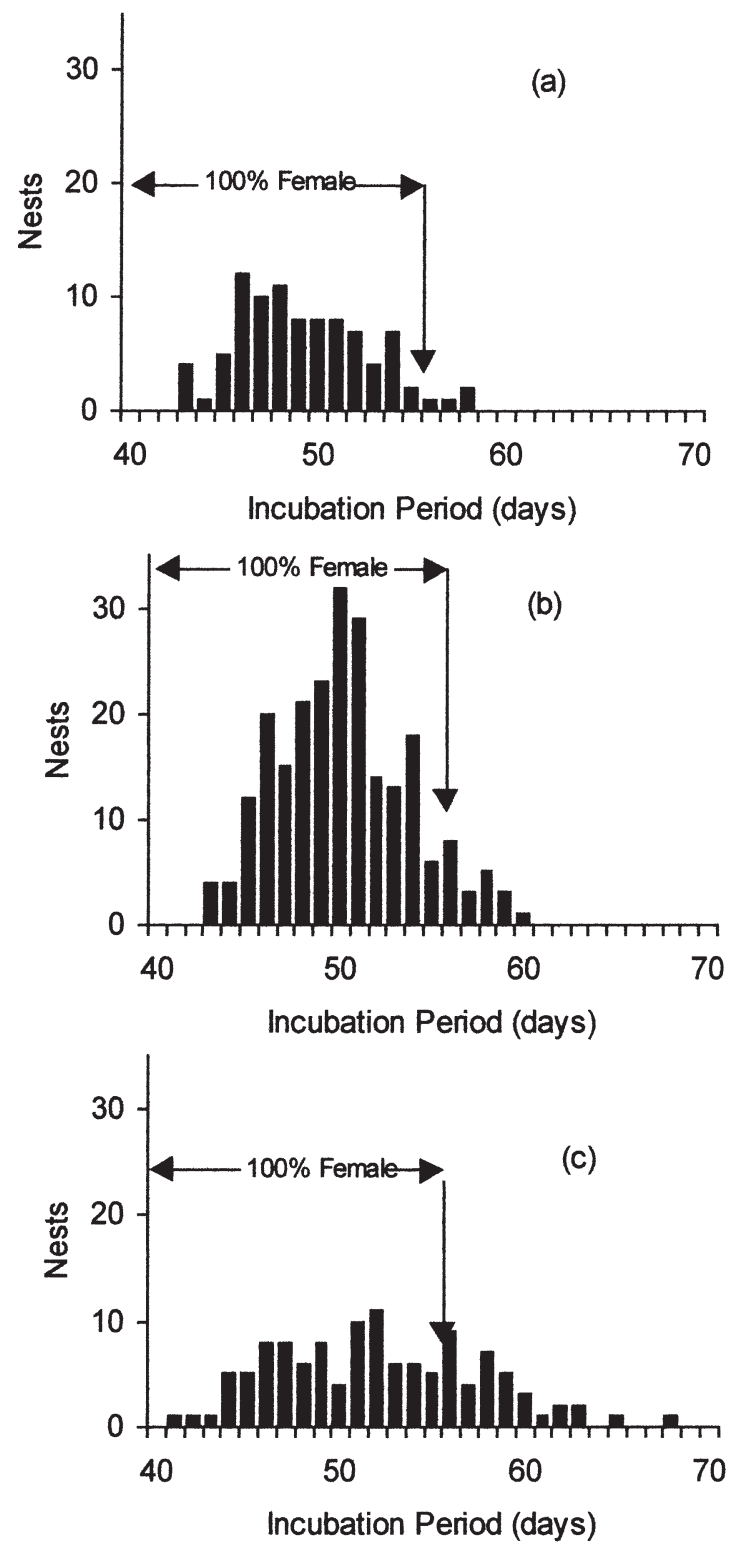

Fig. 5. Frequency histograms illustrating (a) incubation periods of 91 green turtle clutches in 1998 at Alagadi Beach, (b) incubation periods of 231 green turtle clutches over the study period 1993 to 1998 at Alagadi Beach, and (c) incubation periods of 120 green turtle clutches laid at other beaches around the island in 1998. Arrows signify the nests which, in the generation of sex ratios, were assumed to have produced $100 \%$ female hatchlings 


\section{DISCUSSION}

Very few studies have examined natural nest temperatures where nest or egg manipulation has not taken place. The majority of the work conducted to date on TSD in marine turtles has been either laboratory based, with little attempt to replicate any seasonal or diel variation in temperature conditions, or based upon inferences made from sand temperatures. Conditions in the neighbouring sand are likely to vary from that of the nest owing to factors such as metabolic heat, decomposing bacteria and changes in moisture and porosity (McGehee 1990, Godfrey et al. 1997). In particular, the paucity of data based upon actual thermal conditions in nests of green turtles is apparent.

In this study we present the first substantial investigation of natural temperature regimes in nests of the green turtle in the Mediterranean. In this region, the only published work on this subject is that conducted by Kaska et al. (1998), who described the thermal conditions in 5 green turtle nests on a beach on the west coast of Northern Cyprus. However, the methodology of Kaska et al. (1998) involved both post-nesting and pre-hatching excavation to deploy and retrieve temperature loggers, and it is not known if this method of recording is free from artefact. Mean temperatures in our study (ranging between 29.8 and $32.5^{\circ} \mathrm{C} ; \mathrm{n}=18$ ) were comparable with those of Kaska et al. (1998) $\left(29.5\right.$ to $\left.31.3^{\circ} \mathrm{C} ; \mathrm{n}=5\right)$. No regular diel variation was recorded in either study, similar to the findings of Hays et al. (1995) on Ascension Island. This is almost certainly due to the great depths at which green turtle clutches are laid, as diel variation has been recorded in the shallower nests of the loggerhead turtle in Cyprus (Broderick 1997, Kaska et al. 1998).

The composite thermal profile for 1998, produced from the temperature data recorded in the 10 study nests of this year, provides a clear illustration of the conditions experienced within clutches on this beach (Fig. 2a). Whilst the sample size may be small, it is apparent that nearly all clutches laid were likely to have been incubating at temperatures above $29^{\circ} \mathrm{C}$ during the middle third of incubation (Fig. 2b). The temperatures described are high and suggestive of female producing temperatures, when compared to previously published information regarding pivotal temperatures in this species (Miller \& Limpus 1981, Mrosovsky et al. 1984, Standora \& Spotila 1985, Spotila et al. 1987, Godfrey et al. 1996, Godfrey 1997, Kaska et al. 1998).

The clear relationship between temperature and incubation period recorded at this site and the high temperatures and short durations are indicative of a highly female skewed sex ratio. Indeed from this information alone we would expect this population to produce a higher proportion of females than any others of this species studied to date. The sexing of hatchlings supported these expectations, with $>99 \%$ of those sampled at Alagadi Beach being female. It may be argued that through sampling only dead hatchlings, sex biased mortality is influencing our results. This is unlikely to be the case since the results obtained are similar to those of Kaska et al. (1998), who sacrificed live hatchlings in their study.

Our data give us a minimum pivotal incubation period of $56 \mathrm{~d}$, which leads to a maximum pivotal temperature of $29.2^{\circ} \mathrm{C}$. By comparison, Godfrey et al. (1996) estimated the pivotal incubation period in Suriname to be 58.5 d, which would translate to (using Eq. 2 calculated from this present study) a pivotal temperature of $28.4^{\circ} \mathrm{C}$, similar to that estimated for that population $\left(28.8^{\circ} \mathrm{C}\right.$, Mrosovsky et al. $1984 ; 29.1$ to $29.4^{\circ} \mathrm{C}$, Godfrey 1997). All previous studies on green turtles, barring that by Miller \& Limpus (1981), suggest that the pivotal temperature for this species is somewhere between 28 and $30^{\circ} \mathrm{C}$, which translates (using our temperature versus incubation period Eq. 2) to a pivotal incubation period of 53.3 to $60.2 \mathrm{~d}$, encompassing the $56+\mathrm{d}$ estimate from this study.

Within the Mediterranean, the estimated annual female nesting population of green turtles is in the region of 300 to 500 individuals with the majority nesting in Turkey (Groombridge 1990) and Cyprus (approximately one-third; Broderick \& Godley 1996), and a few nests recorded in Egypt and Israel (Kuller 1999, Clarke et al. 2000). Data regarding incubation periods in Turkey are sparse. However, those which have been published are from the most important single nesting beach in the region, Akyatan. There, mean incubation periods have been found to be $53.8 \mathrm{~d}(\mathrm{SE}=0.94, \mathrm{n}=23$; Gerosa et al. 1995) and $53 \mathrm{~d}(\mathrm{SE}=0.56, \mathrm{n}=54$; Gerosa et al. 1997), although in the second study some nests had been subject to prior disturbance by predators. In addition, clutches incubated at an Israeli hatchery also had relatively short incubation periods (mean $52.2 \mathrm{~d}$, $\mathrm{SD}=4.36, \mathrm{n}=21$; Z. Kuller pers. comm.). Although conditions were sought which carefully mimicked those of the natural nests, caution should be used in comparing such an artificial environment. While these other Mediterranean sites have fairly short incubation periods, they are longer than those recorded in Cyprus, but still suggestive of female skewed hatchling production. Similarly the incubation periods of this population are below or at the lower end of the range of those found world-wide (50.6 to $59.5 \mathrm{~d}_{\text {; }}$ see Hirth 1980 for a review).

The significant decrease in incubation periods within the 1998 season (Fig. 3) shows that clutches laid at similar times experience similar thermal conditions, and hence are likely to produce hatchlings of similar sex ratios. The decrease in incubation periods is likely 
to be related to the seasonal profile of increasing temperatures (Fig. 2a). In 1994 and 1995, similar linear relationships were recorded; however in the later starting, longer season of 1993, the relationship between incubation period and laying date was quadratic rather than linear (Broderick 1997). Low levels of nesting in 1996 and 1997 precluded statistical analyses for these years. It is interesting to note that there was a closer relationship between mean temperature for the whole incubation period and incubation duration (Fig. 4a; $\left.\mathrm{r}^{2}=0.79\right)$ than between mean temperature during the middle third of incubation and incubation duration (Fig. $4 b_{;} r^{2}=0.65$ ). The effect of temperature on incubation duration is likely to be one integrated across the whole period, which will explain the increased proportion of variance explained by the former relationship. However, it is important to note that there is still a close relationship between the temperature in the middle third of incubation (the period when sex is determined) and the resultant incubation period.

Although the data collected were from a relatively large sample of nests and hatchlings $(\mathrm{n}=48$ nests; $\mathrm{n}=244$ hatchlings), because of the extreme skew in sex ratio, there was a paucity of male producing nests. Whilst it would be possible to calculate a pivotal incubation period mathematically as per Marcovaldi et al. (1997), this would have such a large confidence range as to have no utility. The fact that no males were produced in nests with incubation periods of below $56 \mathrm{~d}$ is convincing alone and is comparable with that found in the study of loggerhead turtles by Marcovaldi et al. (1997).

Although relatively crude, the minimum estimates of the ratio of female hatchlings produced across the different temporal scales are reliable and suggest that in the 6 yrs of this study Alagadi Beach has been producing a very high percentage of females (86 to $96 \%$ ). Other beaches in the region may be predominantly male producing, possibly due to nests experiencing lower temperatures due to the sand being of a higher reflectance. This pattern has been found in studies on Ascension Island (Hays et al. 1995, 1999). Although other beaches in Northern Cyprus (Fig. 5c) have nests with incubation periods longer than those at Alagadi in the same season (Fig. 5a), they are still likely to have profoundly female biased hatchling production.

If the skewed sex ratio continues through to adulthood and natal philopatry for both sexes is in operation, it might be a concern that there would be too few males to allow successful fertilisation of available females. There is no evidence to suggest an infertility problem leading to low hatching success. Excluding nests which fail due to inundation or predation, nests in Cyprus hatch with an annual mean success of 83.8 to $85.3 \%$ (1992 to 1995; Broderick \& Godley 1996).
Because of the discrete nature of the Mediterranean green turtle population (Bowen et al. 1992, Encalada et al. 1996), it is vital to discover if such highly biased hatchling production occurs elsewhere in the region. Given that the ratio of hatchlings produced in the Eastern Mediterranean would appear biased towards females, there is a need to investigate whether this bias persists in the wild population to the juvenile and adult stages. This would be possible using the techniques that demonstrated that, at least in some regions, the female bias of North American loggerhead turtles is present in the live juvenile population (Wibbels et al. 1991). Alternatively, sex ratios of stranded animals could be investigated.

Assuming these female biases are widely present in this relatively isolated population, plans for conservation management must take these results into account. Transplanting of nests may further bias sex ratios. Nests should be moved to an area where similar thermal conditions exist as at the primary site. Managers should be vigilant against transplanting from a possible male producing area to a safe female producing area, and only move nests if they are guaranteed to be lost without action. Clutches deposited early in the season may have a great level of importance with regard to producing enough males. This should be considered for example when prioritising limited management resources to prevent nest predation. The difficulty in determining a pivotal temperature for incubation period from a population with such a highly skewed sex ratio of hatchling production highlights the need for a laboratory based pivotal temperature to be demonstrated for this regional population.

Acknowledgements. The authors would like to thank all members of Glasgow University Turtle Conservation Expedition 1992 to 1998; special thanks to Damla Beton and Dr Tunay Beton and staff at Lefkosa Hospital for histological assistance. This work was supported by the British Association of Tortoise Keepers, British Chelonia Group, British Ecological Society, Carnegie Trust, Cross Trust, European Commission DG1B/1A, Institute of Biology, Glasgow Natural History Society, Glasgow University Court, MEDASSET UK, People's Trust for Endangered Species, North of England Zoological Society, and Zebra Foundation. Logistical support was given by the Department of Environmental Protection and the Society for the Protection of Turtles in Northern Cyprus; unpublished data were provided by Zeev Kuller, Israel Nature and National Parks Protection Authority.

\section{LITERATURE CITED}

Billett FS, Collins P, Goulding DA, Sutherland J (1992) The development of Caretta caretta at $25-34^{\circ} \mathrm{C}$ in artificial nests. J Morphol 213:251-263

Bowen BW, Meylan AB, Ross J, Limpus C, Balazs G, Avise JC (1992) Global population structure and natural history of the green turtle (Chelonia mydas) in terms of matriarchal phylogeny. Evolution 46:865-991 
Broderick AC (1997) The reproductive ecology of marine turtles, Chelonia mydas and Caretta caretta, nesting at Alagadi, northern Cyprus, eastern Mediterranean. PhD thesis, University of Glasgow

Broderick AC, Godley BJ (1996) Population and nesting ecology of the green turtle, Chelonia mydas, and loggerhead turtle, Caretta caretta, in northern Cyprus. Zool Middle East 13:27-46

Chevalier J, Godfrey MH, Girondot M (1999) Significant difference of temperature-dependent sex determination between French Guiana (Atlantic) and Playa Grande (Costa Rica, Pacific) leatherbacks (Dermochelys coriacea). Ann Sci Nat (Paris) 20:147-152

Clarke M, Campbell AC, Salama Hameid W, Ghoneim S (2000) Preliminary report on the status of marine turtle nesting populations on the Mediterranean coast of Egypt. Biol Conserv 94:363-371

Dutton PH, Whitmore CP, Mrosovsky N (1984) Masculinisation of leatherback turtle hatchlings from eggs incubated in Styrofoam boxes. Biol Conserv 31:249-264

Encalada SE, Lahanas PN, Bjorndal KA, Bolten AB, Miyamoto MM, Bowen BW (1996) Phylogeography and population structure of the Atlantic and Mediterranean green turtle (Chelonia mydas): a mitochondrial DNA control region sequence assessment. Mol Ecol 5:473-484

Georges A, Limpus C, Stoutjesdijk R (1994) Hatchling sex ratio in the marine turtle Caretta caretta is determined by proportion of development at a temperature, not daily duration of exposure. J Exp Zool 270:432-444

Gerosa G, Casale P, Yerli SV (1995) Report on a sea turtle nesting beach study (Akyatan, Turkey), 1994. Chelon, Marine Turtle Conservation and Research Program (Tethys Research Institute), Rome

Gerosa G, Yerli S, Aureggi M, Conti C (1997) Report on a sea turtle nesting beach study (Akyatan, Turkey) 1997. Chelon, Marine Turtle Conservation and Research Program (Tethys Research Institute), Rome

Godfrey MH (1997) Sex ratios of sea turtle hatchlings: direct and indirect estimates. $\mathrm{PhD}$ thesis, University of Toronto

Godfrey MH, Barreto R, Mrosovsky N (1996) Estimating past and present sex ratios of sea turtles in Suriname. Can J Zool 74:267-277

Godfrey MH, Barreto R, Mrosovsky N (1997) Metabolicallygenerated heat in sea turtles' nests and its potential effect on the sex ratio of hatchlings. J Herpetol 31:616-619

Groombridge B (1990) Marine turtles in the Mediterranean: distribution, population status, conservation. A report to the Council of Europe Environment Conservation and Management Division. World Conservation Monitoring Centre, Cambridge

Hays GC, Adams CR, Mortimer JA, Speakman JR (1995) Inter- and Intra-beach thermal variation for green turtle nests on Ascension Island, South Atlantic. J Mar Biol Assoc UK 75:405-411

Hays GC, Godley BJ, Broderick AC (1999) Long-term thermal conditions on the nesting beaches of green turtles on Ascension Island. Mar Ecol Prog Ser 185:297-299

Hirth HF (1980) Some aspects of the nesting behavior and reproductive biology of sea turtles. Amer Zool 20:507-523

Janzen FJ, Paukstis GL (1991) Environmental sex determination in reptiles: ecology, evolution and experimental design. Q Rev Biol 66:149-179

Kaska Y, Downie JR, Tippett R, Furness R (1998) Natural temperature regimes for loggerhead and green turtle nests in the eastern Mediterranean. Can J Zool 76:723-729

Kuller Z (1999) Current status and conservation of marine turtles on the Mediterranean coast of Israel. Mar Turt News $86: 3-5$

Limpus CJ, Reed P, Miller JD (1983) Islands and turtles: the influence of choice of nesting beach on sex ratio. In: Baker JT, Carter RM, Sammarco PW, Stark KP (eds) Proceedings: inaugural Great Barrier Reef conference. James Cook University Press, Townsville, p 397-402

Marcovaldi MA, Godfrey MH, Mrosovsky N (1997) Estimating sex ratios of loggerhead turtles in Brazil from pivotal incubation durations. Can J Zool 75:755-770

McGehee MA (1990) Effects of moisture on eggs and hatchlings of loggerhead sea turtles (Caretta caretta). Herpetologica 46:251-258

Miller JD, Limpus CJ (1981) Incubation period and sexual differentiation in the green turtle Chelonia mydas L. In: Banks C, Martin A (eds) Proceedings of the Melbourne herpetological symposium zoological board of Victoria, 1981. Zoological Board of Victoria, Parkville, p 66-73

Morreale SJ, Ruiz GJ, Spotila JR, Standora EA (1982) Temperature-dependent sex determination: current practices threaten conservation of sea turtles. Science 216: $1245-1247$

Mrosovsky N (1988) Pivotal temperatures for loggerhead turtles (Caretta caretta) from northern and southern nesting beaches. Can J Zool 66:661-669

Mrosovsky N (1994) Sex ratios of sea turtles. J Exp Zool 270: $16-27$

Mrosovsky N, Pieau C (1991) Transitional range of temperature, pivotal temperatures and thermosensitive stages for sex determination in reptiles. Amphib-Reptilia 12:169-179

Mrosovsky N, Provancha J (1989) Sex ratio of loggerhead sea turtles on a Florida beach. Can J Zool 67:2533-2539

Mrosovsky N, Provancha J (1992) Sex ratio of hatchling loggerhead sea turtles: data and estimates from a 5-year study. Can J Zool 70:530-538

Mrosovsky N, Yntema CL (1980) Temperature dependence of sexual differentiation in sea turtles: implications for conservation practices. Biol Conserv 18:271-280

Mrosovsky N, Dutton PH, Whitmore CP (1984) Sex ratios of two species of sea turtle nesting in Suriname. Can J Zool 62:2227-2239

Mrosovsky N, Bapistotte C, Godfrey MH (1999) Validation of incubation durations as an index of sex ratio of sea turtle hatchlings. Can J Zool 77:831-835

Spotila JR, Standora EA, Morreale SJ, Ruiz GJ (1987) Temperature dependent sex determination in the green turtle (Chelonia mydas): effects on the sex ration on a natural beach. Herpetologica 43:74-81

Standora EA, Spotila JR (1985) Temperature dependent sex determination in sea turtles. Copeia 1985:480-482

Wibbels T, Martin RE, Owens DW, Amos MS Jr (1991) Female-biased sex ratio of immature loggerhead sea turtles inhabiting the Atlantic coastal waters of Florida. Can J Zool 69:2973-2977

Wibbels T, Hillis-Star ZM, Phillips B (1999) Female biased sex ratios of hatchlings hawksbill sea turtles from a Caribbean nesting beach. J Herpetol 33:142-144

Yntema CL, Mrosovsky N (1980) Sexual differentiation in hatchling loggerheads (Caretta caretta) incubated at different controlled temperatures. Herpetologica 36:33-36

Zar JH (1999) Biostatistical analysis, 4th edn. Prentice Hall, Englewood Cliffs, NJ

Submitted: October 15, 1999; Accepted: February 17, 2000

Proofs received from author(s): August 1, 2000 